\title{
A Study on Public English Course Books in Higher Vocational College-Taking 21st Century Practical College English as a Case
}

\author{
Chun-yi LI \\ International Education Department, Hainan College of Economics and Business \\ Haikou, China
}

Keywords: Vocational education, English course book, Analysis, Evaluation.

\begin{abstract}
Century Practical College English was a set of newly -published course book by Fudan University Press. It is now widely used by colleges. Under such a circumstance, the evaluation of college English course book is now increasing. The author intends to understand the current use of this set of course books and existing problems to discover the consistence, applicability, adaptability and flexibility of $21 \mathrm{st}$ Century Practical College English. The author firstly introduced the purpose of the research, then she made an internal evaluation of the course book adopted by her teaching college by the guidance of previous studies on evaluation at home and abroad. It also analyzed the current use of the course book by using the data collected from the teachers', the students' questionnaires and classroom observation. From the results of this study the author concluded that 21st Century Practical College English is a set of course books that generally meets the needs of college English curriculum requirements in our country. The structure and design of the course book can well meet the needs of both teachers and students. But it is not sufficient in cultivating overall skills and teaching methods.
\end{abstract}

\section{Purpose of the Research}

A vital purpose of this study is to give a scientific and objective evaluation of course books of 21st Century Practical College English (hereafter 21st CPCE) in Hainan College of Economics and Business in Hainan. The author makes a conclusion of materials evaluation theory and does relevant research on 21st CPCE. The author tries to explore the usefulness and feasibility of the course books in Hainan in which teaching materials play important roles for college students who can acquire their target language both in and out of classroom by analyzing the writing ideology, the structure, the editing and design, the organization and the viewpoints of its course, language and language teaching. An evaluation is made to help ascertain and make it clear whether the currently-used college English course books show the developments and achievements of language learning theory and syllabus design, and whether the course books are useful for achieving the objectives set by Trial Implementation in 2000---the Basic Requirements for Higher Vocational-Technical Colleges English Course.

\section{Course Book Package of 21st CPCE}

21st Century Practical College English consists of students' books, comprehensive workbooks, teachers' reference books and PowerPoint of 21st CPCE. Introductions for each part are as follows. 
There are totally four students' books which form the core of the package. Each one includes the training of listening, speaking, reading and writing, at the word level, sentence level and discourse level. The comprehensive workbooks, which are optional and subsidiary material for the comprehensive training, go along with the students' book. The teachers' reference books can provide extra support and help for teachers to start their teaching. As for the PowerPoint, it is convenient for both teachers and students and can be used in conjunction with course books. The students' books are important for language training. There are 8 units for each book and each unit contains the following contents:

\section{Listening and Speaking}

This section contains comprehensive exercises for both listening and speaking. The exercises are designed according to the practical needs of graduation. Firstly, the students are required to understand the topic and the new words usually introduced by the teacher as a warm-up exercise. Secondly they will listen to the short passages, short conversations and situational dialogues. After each part, they will practice their oral English by answering the questions or giving a role-play. At last, a discussion on the topic will be given to the students as their homework.

\section{Reading and Writing}

In this section, three texts are introduced. Each one is related to a topic. Students will learn new words and expressions. The comprehension of the text will be done with the help of teacher as well as the exercises. However, as for the freshman and sophomore, only Text A and B are necessary for learning, and Text $\mathrm{C}$ is given to the students who are interested in the topic and are good at learning English. At the end of the reading part, basic reading skills are introduced for students to help improve their skills. The writing work consists of sentences writing and practical writing.

\section{Practical Section}

The training in this section aims to improve students' professional skills and quality. It contains grammar review, practical writing and basic skills for reading. This part is included in each unit.

This series of course books adopts the advantages of similar course books at home and abroad. It is compiled on the basis of features of talent cultivation for Higher Vocational-Technical Education and the achievements of teaching reform.

\section{Suggestions for Teaching}

To make teaching more effective, some suggestions are given by the author after analyzing the questionnaires.

First of all, teachers should pay attention to the needs of learners since there are so much content covered in the textbook. Not all the content meets the needs of learners. Course book is needed to be adapted if teachers find it not ideal in teaching. There are several ways for teachers to adapt materials. They can leave out some parts of materials or add some materials which can be either published or written by the teachers themselves. They can also use some other suitable materials to replace those unsuitable ones.

Secondly, teachers are not only responsible for teaching students the knowledge but guiding them to master learning strategies and giving necessary consultancy. To make teaching more effective, students also need to conduct automatic and cooperative 
learning. Therefore, teachers should change their teacher-centered teaching method and adopt student-centered approach instead. Students will be given more chances to express their ideas in class and learning is not so boring for them any more. In practical teaching, the author divides her students in each class into four or five groups. Students are asked to do some team work such as role-play, topic discussion in class. Good English learners in each group are required to help those poor learners. The author also designs some homework requiring group work for students to prepare after class. The author finds that the students are quite willing to take part in group work and the enthusiasm in learning is absolutely increased.

Finally, students are eager to learn more knowledge out of their course book, which raise many requirements for teachers. For example, students are willing to do more speaking tasks in class, so teachers are required to promote their oral English ability to make their teaching more attractive. What is more, because students have their English classes in multi-media classrooms in Hainan College of Economics and Business, they are eager to learn more from the internet. Teachers should devote more time to learning the internet and downloading some useful teaching materials for their teaching.

\section{Analysis of Interview}

Several experienced teachers from the other Higher Vocational-Technical Colleges are interviewed by the author to get a better understanding of the use of the course book. The contents include the use of the course book, the needs and interest in learning, integrated skills training, strength and weakness.

\section{The use of the Course Book}

Most of the teachers agree that Course Book 1 is satisfying in general. However, some say that parts of the contents in the course book are a little difficult. Students can finish this kind of study load with the help of teachers' instruction. For some good learners of English, they think this course book is just simple to learn, and they need a more informative one which can cover more foreign cultures and broaden their horizons.

\section{Needs and Interest in Learning}

Basically speaking, the teachers believe that this course book can meet students' needs and interests in learning. For those students who are not doing well in English, this book can arouse their interests with simple words and sentences. Teachers are told by the students that the topics covered in the course book are amusing and informative, what is more important is that they are related to their experiences and make the learning process meaningful and interesting. The texts in the course book not only teach the students the language, but also train their learning skills.

\section{Integrated Language Training}

Teachers also believe that this course book focus on training students' English listening, speaking, reading and writing skills. There are different kinds of exercises aiming at testing students' different aspects of mastery of language. However, one teacher finds that the materials in listening part are not authentic enough to train the students' abilities. Some sentences are too long to write down. The other teachers agree this point. It will be better if the course book can combine listening skills with other skills. Talking about reading materials, teachers think they are well selected, but some texts are only learnt by the students themselves because of a tight teaching schedule. As a result, most 
of the students are not willing to learn the texts if they are not taught in class. As for writing training, it can provide enough exercises training.

\section{Strength and Weakness}

Teachers in Hainan College of Economics and Business have access to multimedia and CD-ROM for teaching and they can make good use of the PowerPoint which goes along with the course book. Students are more willing to learn with the PowerPoint in classroom. Teaching becomes more effective and interesting. But some teachers have little access to multimedia and CD-ROM, teaching is only given in usual classroom. Therefore, teachers need to talk a lot to explain the text, but the students feel bored if teaching lasts long. In addition, teachers who mainly use course book for teaching focus on listening training instead of oral training. So listening skill training should be combined with other comprehensive English skills training to improve students' listening ability more effectively. According to the Basic Requirements, Higher Vocational-Technical Education requires teachers to train students' comprehensive English skills.

\section{Results of Classroom Observation}

We can actually find out how the teachers use the course book by observing their classes. So I attended 6 teachers' classes and observed the actual situation to find out the truth. At the same time, I interviewed the teachers who gave the classes as well as the students who attended the class. Teachers are expected to give public classes as a kind of self-improvement in teaching among teachers every semester. It is really a good method for improving one's teaching because there are excellent and experienced teachers who will provide this kind of lessons for the young teachers to learn from them. Every teacher is welcome to attend the public lessons if they are free. The young teachers are also required to prepare for the public lessons in order to evaluate their teaching and by the way, find out one's strength and weakness. As for our college, it was newly established in 2005, so some teachers are young and come to the college less than five years. Therefore, most of the public lessons are given by the young teachers. But teachers are usually nervous for the public classes and they don't think it is comfortable for being observed.

I chose Ms Wu's classes and attended her classes many times. I had my reasons for it. First of all, Ms Wu and I come from the same place and she is just like my elder sister who is willing to teach me lots of things. Therefore, it is convenient for me to exchange ideas with her. Second, she is a really experienced one in our department and is invited to provide public lesson as a teaching example by the administration. It is a good chance for me to attend her class. At last, to some degree, most of our teachers respect her a lot and take her as a teaching example. So she has a say in the public English class group.

\section{Ms Wu's Public Class}

Ms Wu selected Text A, Unit Three in course book I as a public lesson. The topic of the text is "I Can't Accept Not Trying", which is written by Michael Jordan. The students are majoring in International Business and Trade, from Class One. Forty - five of them were sitting in pairs at desks in five groups facing a teaching platform. The lesson was given in a multimedia classroom. There is a big screen set on the right side of the classroom for the students to look at teachers' instructions. The students were quite excited before the class began. When $\mathrm{Ms} \mathrm{Wu}$ entered the classroom, the students soon 
stopped talking and looked at her. Ms Wu used the computer to get everything ready and began her class by greeting the students. "Good morning, my boys and girls! How are you doing today?" Almost all the students responded actively to her greeting. And after that, Ms Wu invited the students to look at the screen and she had a video to show them.

I found the students became quite curious and excited. Ms Wu said, "Please pay attention to the leading role of the video and tell me who he is." Then she wrote down the question on the blackboard for reference. The students obviously focused on the screen and told the answer as quickly as possible.

After "lead-in", Ms Wu began to turn to Text A. "we know Michael Jordan is a very famous player in the world. However, how much do you know about him?" the students became excited and began to say something. Ms Wu invited several of them to introduce Michael Jordan as much as possible. After that, $\mathrm{Ms} \mathrm{Wu}$ appreciated their participation and asked, "Do you know his famous quotes?" The word "quote" was a strange one for the students and they became interested in it and hoped to understand it more. $\mathrm{Ms} \mathrm{Wu}$ explained the Chinese meaning to the students with two example sentences and they read the title of Text A quickly. The students, along with I, think it as an interesting class. The students actively participated in the lesson and they tried as much as possible to express themselves with the help of their teacher.

This lesson was regarded as a very successful one. But $\mathrm{Ms} \mathrm{Wu}$ also expressed her gratitude to her students: "without my students' good cooperation in the classroom, I can not make it a smooth one..." Every time when the lessons are observed, students are well disciplined, active and more cooperative. At the same time, $\mathrm{Ms} \mathrm{Wu}$ said that in the usual class, the situation would be different. It is not easy to find out a creative way to teach, most of the teachers adopt a conservative and traditional way to use the course book.

\section{Ms Wu's Usual Class}

Two days after Ms Wu's public class, I attended Ms Wu's usual class in the same classroom. She made a brief revision of what they learnt the day before by asking some questions related to the text. Only several students made responses and obviously they were not so active. Ms Wu started to check the answers of the exercises on the course book one by one and explained some phrases and sentence patterns. She also explained grammar rules and language points on the blackboard with illustrated examples and the students actively copied them in their own notebooks.

It was really different from her public class. She did not pay attention to the authentic learning of their students but put more emphasis on the restricted content and grammar rules. After class, Ms Wu said she just used the textbook and implemented the syllabus according to the course book and the teacher's book arrangements.

\section{Implication}

The results indicate that 21st Century Practical College English is suitable for most Higher Vocational-Technical Education students. Implication from the findings is as follows. In the present situation, it is necessary to adapt materials for English course. Teachers should learn to adapt their existing materials and resources for better use if materials are not available and material compilation is very energy-and-time consuming. They should also pay more attention to students' needs which are considered to be the 
basis of material adaptation. Another skill teachers should have is to match the content in materials to real content.

This study has found students' demands. They hope that there are more interesting and meaningful contents in the course book and teachers can provide more interactive and communicative classroom activities to help improve their language ability. Therefore, more interactive and communicative materials should be added into classroom to ignite students' interests.

\section{References}

[1] Brown. J. D., The elements of language curriculum: A systematic approach to program development, Foreign Language Teaching and Research Press, Beijing, 2001.

[2] Brown. H. D., Teaching by Principles: An Interactive Approach to Language Pedagogy, Foreign Language Teaching and Research Press, Beijing, 2001.

[3] Cunningsworth, A., Choosing Your Coursebook, Shanghai Foreign Language Education Press, Shanghai, 2002.

[4] Cunningsworth, A., Choosing Your Coursebook, Macmillan Publishers Limited, London, 1995.

[5] Wei Liu. Course Book Evaluation on New Horizon College English [D]. Wuhan: Wuhan University of Technology, 2006: 25. (In Chinese)

[6] O’Neill, R., Why use textbook, J. ELT. Journal 36(2), (1982)101-104.

[7] Rivers, Wilga, M., Interactive Language Teaching, Foreign Language Teaching And Research Press, Beijing, 2000.

[8] H. B. Xu, on the evaluation of college English, J. Journal of Southwest Agricultural University Social Science Edition, 2003(1): 75-78. (In Chinese) 